\title{
Pengaruh Arah dan Tebal Irisan Rimpang Terhadap Rendemen Flavonoid, Berat Kering dan Performa Simplisia Umbi Garut (Maranta arundinacea L.) Setelah Pengeringan
}

\section{The Effect Slicing of Rhizome to Flavonoid Rendemen, Dry Weight and Quaility Simplicia Umbi Garut (Maranta aundinacea L.) after Drying}

\author{
Devi Ermawati, Erma Prihastanti, Endah Dwi Hastuti* \\ Program Studi Biologi, Fakultas Sains dan Matematika, Universitas Diponegoro \\ Jl. Prof. Soedarto, SH, Tembalang, Semarang 50275, Indonesia \\ Email :endah_pdil@yahoo.com
}

Diterima 21 Juli 2021 / Disetujui 12 Agustus 2021

\begin{abstract}
ABSTRAK
Simplisia merupakan bahan alami sebagai bahan pembuatan obat yang belum mengalami pengolahan. Pengirisan merupakan salah satu tahap penting dalam pembuatan bahan simplisia untuk mempermudah dalam proses pengepakan, penyimpanan dan penggilingan. Pengirisan dapat dilakukan secara melintang atau membujur. Tujuan penelitian ini adalah mengetahui pengaruh arah dan tebal irisan rimpang terhadap rendemen flavonoid, berat kering dan performa simplisia umbi garut (Maranta arundinacea L.) setelah pengeringan. Penelitian ini dilaksanakan di Laboratorium BSF Tumbuhan UNDIP. Rancangan yang digunakan adalah Rancangan Acak Lengkap (RAL) pola faktorial $2 \mathrm{X} 2$ dengan perlakuan kombinasi ketebalan ( $3 \mathrm{~mm}$ dan $5 \mathrm{~mm}$ ) dan arah irisan (membujur dan melintang). Parameter penelitian meliputi berat kering dan performa simplisia yang meliputi warna, kekerasan, dan aroma pada simplisia kering. Analisis data menggunakan Anova dengan taraf kepercayaan 95\%. Hasil penelitian menunjukkan arah irisan berpengaruh terhadap berat kering simplisia, sedangkan interaksi antara tebal dan arah irisan tidak berpengaruh terhadap berat kering simplisia umbi garut. Arah irisan berpengaruh terhadap berat kering dan performa simplisia umbi garut, tebal irisan berpengaruh terhadap rendemen flavonoid.
\end{abstract}

Kata kunci: bahan alami, penyimpanan, warna,

\begin{abstract}
Crude simplisia is natural material for making medicine, which has not undergo processing, packing, drying and saving. Slicing is an important step in making medicine because in this process the loss of some parts could ease the process of packing and milling. Slicing could be done diagonally or longitudinally. A Different way of slicing could affect this simplisia. This study aimed to examine the influence of slicing direction, the thickness of slices, and its combination on the dry weight and the performance of arrowroot. This research was conducted in the Laboratory of BSF Tumbuhan UNIDIP. The design used was Completely Randomized Design with combination treatment of thickness $(3 \mathrm{~mm}$ and $5 \mathrm{~mm})$ and slice direction (diagonally and longitudinally). The parameter of this research used dry weight by weighing after the drying process and the performance (by measuring color, hardness, and the aroma of dried simplisia). The data analysis used Analysis of Variance. The findings showed that slice direction influenced the weight loss on simplisia, but the interaction did not influence on the dry weight of arrowroot simplisia. Slice direction affects dry weight and performance of arrowroot simplicia, slice thickness affects flavonoid yield.
\end{abstract}

Keywords: simplisia, natural material, color 


\section{PENDAHULUAN}

Umbi garut memiliki banyak keunggulan, yakni dapat digunakan sebagai pengganti bahan makanan pokok, dan sebagai obat-obatan. Umbi garut dapat digunakan untuk mendinginkan perut dan disentri, obat eksim, obat tapal luka, dan memperbanyak produksi ASI. Menurut Indrawati (2013) Selain itu umbi garut memiliki nilai IG (Indeks Glikemiks) yang rendah, dibandingkan umbi-umbian yang lain seperti gembili, kimpul, ganyong, dan ubi jalar. Hal ini dapat memberikan manfaat menurunkan kadar gula darah bagi penderita diabetes atau kencing manis. Penyakit tersebut disebabkan karena tingginya gula darah. Umbi garut juga mengandung senyawa bioaktif sebagai antioksidan. Fenol dalam umbi garut segar sebesar $0,16 \quad \mathrm{~g} / 100 \quad \mathrm{~g}$. sedangkan kadar $\begin{array}{llll}\text { flavonoidnya sebesar } & 0.15 & \mathrm{~g} / 100 & \mathrm{gr}\end{array}$ (Koswara,2013).

Menurut Balai Besar Penelitian dan Pengembangan Tanaman Obat dan Obat Tradisional (B2P2TOOT) (2015) untuk bahan simplisia berupa umbi garut harus dihindari perajangan yang terlalu tipis agar dapat mencegah berkurangnya flavonoid karena akan menguap. Selain itu, perajangan yang terlalu tipis juga menyebabkan simplisia mudah rusak saat dilakukan pengeringan dan pengemasan. Sebaliknya, jika terlalu tebal maka kandungan air dalam simplisia akan sulit dihilangkan. Tebal perajangan yang baik pada simplisia adalah $3 \mathrm{~mm}$ dan $5 \mathrm{~mm}$ sehingga diperoleh ketebalan ideal simplisia kering yaitu 3 $\mathrm{mm}$ dan $5 \mathrm{~mm}$ dan dilakukan pengirisan secara membujur. Tujuan dan alasan pengeringan yaitu untuk mendapatkan simplisia yang tidak mudah rusak, sehingga dapat disimpan dalam waktu yang lebih lama. (Hasan dkk,2011).

\section{METODE PENELITIAN}

Penelitian dilaksanakan di Laboratorium BSFT (Biologi Struktur dan Fungsi Tumbuhan) Jurusan Biologi Universitas Diponegoro bulan Desember-Januari 2021. Bahan yang digunakan pada penelitian ini adalah dan umbi garut berumur 6 bulan diambil dari kebun petani di desa Bantar, Kecamatan Wanayasa, Kabupaten Banjarnegara.
Alat yang digunakan pada penelitian ini yaitu seperangkat alat destilasi.

\section{Perlakuan Sampel}

Rimpang umbi garut hasil panen dicuci, disortir dan dibersihkan dari kotoran. Rimpang kemudiaan ditiriskan selama 1 hari. Selanjutnya rimpang diiris dengan variasi arah: membujur (A1) dan melintang (A2); dan variasi ketebalan: $3 \mathrm{~mm}$ (T1) dan $5 \mathrm{~mm}$ (T2). Masingmasing perlakuan irisan rimpang ditimbang seberat $50 \mathrm{~g}$. Selanjutnya irisan rimpang dikeringkan menggunakan oven pada suhu 50oC selama 108 jam. masing-masing perlakuan diulang sebanyak 4 kali.

\section{Rendemen Flavonoid Simplisia Umbu Garut}

Rendemen flavonoid dapat diperoleh dengan maserasi yaitu $10 \mathrm{~g}$ serbuk umbi garut dimaserasi menggunakan larutan etanol 70\% dan HCL 3 tetes serta magnesium $0,5 \mathrm{~g}$. Kadar flavonoid dihitung berdasarkan kurva kalibrasi hasil pembacaan dari alat spektrofotometer UV-Vis, dan persamaan regresi linier dengan menggunakan hukum Lambert-Beer tahun 1970.

\section{Pengukuran Berat Kering dan Performa Simplisia}

Setelah dikeringkan pada suhu $50 \mathrm{oC}$ selama 108 jam, rimpang simplisia ditimbang menggunakan timbangan analitik. Performa simplisia yang diamati meliputi warna, kekerasan dan aroma setelah pengeringan. Pengamatan dilakukan secara deskriptif. Warna simplisia ditentukan dengan membandingkan warna antar perlakuan. Kekerasan simplisia diamati dengan cara ditekan atau dipatahkan, sedangkan aroma dengan cara membandingkan aroma antar perlakuan.

\section{Rancangan Percobaan}

Penelitian ini dirancang dengan rancangan acak lengkap (RAL) dengan pola faktorial $2 \mathrm{X} 2$. Faktor tersebut antara lain faktor ketebalan, yang terdiri dari $3 \mathrm{~mm}$ dan $5 \mathrm{~mm}$, serta faktor irisan yaitu arah irisan membujur dan melintang. Variabel bebas meliputi ketebalan dan arah irisan umbi garut 
sedangkan variabel terikat meliputi berat kering, kadar flavonoid, dan performa (warna, kekerasa, dan aroma) dengan 4 kali ulangan.

\section{Analisis Data}

Data kuantitatif dianalisis dengan ANOVA (analisis of variance). Apabila hasil uji F menunjukkan hasil yang berbeda nyata, maka dilanjutkan dengan uji lanjut Duncan's Multiple Range Test (DMRT) dengan taraf kepercayaan $95 \%$.

\section{HASIL DAN PEMBAHASAN}

\section{Rendemen Flavonoid}

Hasil analisis berat kering simplisia umbi garut diperlakukan dengan arah dan tebal irisan berbeda disajikan pada Tabel 1. Data hasil analisis uji lanjut DMRT menunjukkan ketebalan berpengaruh nyata terhadap rendemen flavonoid. Ketebalan yang paling optimal dalam menghasilkan rendemen flavonoid adalah $5 \mathrm{~mm}$ yaitu $1,03 \%$. Menurut Hasan dkk (2011) ketebalan tidak terlalu tipis, flavonoid yang dihasilkan akan optimal. Flavonoid merupakan senyawa yang mudah menguap, oleh karena itu pengirisan lebih tipis akan menghilangkan flavonoid cukup hanyak selama proses pengeringan dan kadar flavonoid menjadi turun.

Irisan dengan ketebalan $5 \mathrm{~mm}$ memiliki kandungan flavonoid yang lebih tinggi dibandingkan ketebalan irisan $3 \mathrm{~mm}$ sehingga ketebalan $5 \mathrm{~mm}$ paling efisien dalam proses isolasi flavonoid. Menurut Anwar dkk (2017), umbi garut bagian kortek dan silinder pusat terdiri atas sel parenkim, sel sekresi dan berkas pengangkut. Flavonoid banyak tersimpan di dalam sel parenkim, di dalam saluran minyak, di dalam rongga dan lisigen ataupun terkandung dalam semua jaringan. Jika irisan lebih tebal maka jaringan yang mengandung flavonoid semakin banyak, yaitu tebal $5 \mathrm{~mm}$.

Arah irisan berdasarkan hasil penelitian tidak menunjukkan adanya pengaruh yang nyata terhadap rendemen flavonoid. Menurut Harmayani (2011) Adanya pengirisan akan memecah sel yang mengandung flavonoid, dan sedikit banyak akan hilang karena penguapan, selanjutnya akan mengurangi kadar flavonoid. Rendemen flavonoid terendah diperoleh pada pengirisan membujur 3 $\mathrm{mm}$ (AITI) dan pengirisan melintang $3 \mathrm{~mm}$ (A2TI) masing- masing sehanyak $0,7 \%$.

Dari hasil tersebut ketebalan irisan $3 \mathrm{~mm}$ baik arah irisan melintang maupun membujur menunjukkan rendemen lavonoid yang terendah. Menurut Hasan dkk (2011) irisan melintang memiliki kandungan flavonoid lebih tinggi, namun tidak berbeda spesifik dengan pengirisan secara melintang. Interaksi antara arah dan tebal irisan simplisia umbi garut tidak berbeda nyata terhadap rendemen flavonoid. Hasilnya yaitu $(p>0,05)$.

Tabel 1. Uji lanjut DMRT tebal irisan terhadap rendemen flavonoid simplisia umbi garut.

\begin{tabular}{ccc}
\hline \multirow{2}{*}{ Tebal irisan } & $\mathrm{n}$ & \multicolumn{2}{c}{ Mean } \\
\cline { 2 - 3 } T1 $(3 \mathrm{~mm})$ & 4 & $0,70^{\mathrm{a}}$ \\
$\mathrm{T} 2(5 \mathrm{~mm})$ & 4 & $1,03^{\mathrm{b}}$ \\
\hline Keterangan: angka-angka yang diikuti huruf yang \\
sama pada kolom yang sama tidak \\
berbeda nyata pada taraf 95\% dengan \\
menggunakan uji DMRT
\end{tabular}

\section{Berat Kering Simplisia}

Hasil analisis berat kering tanaman Umbi Garut yang diperlakukan dengan arah dan tebal irisan berbeda di sajikan pada Tabel 2. Hasil uji DMRT (Tabel 2) menunjukkan bahwa arah pengirisan rimpang umbi garut berpengaruh signifikan terhadap berat kering simplisia $(\mathrm{p}<0,05)$, tetapi tebal irisan serta interaksi arah dan tebal irisan rimpang lempuyang wangi tidak berpengaruh signifikan terhadap berat kering simplisia $(\mathrm{p}>0,05)$.

Data hasil analisis uji lanjut DMRT menunjukan arah irisan berpengaruh nyata terhadap berat kering. Arah yang paling optimal untuk menghasilkan berat kering, yaitu arah irisan melintang 11,68 g. Menurut Aprilia (2017) semakin besar luas permukaan simplisia maka laju penguapan semakin cepat, dan jika luas permukaan kecil maka laju penguapan semakin lambat.

Menurut Ines (2016) perbedaan luas permukaan simplisia memberikan pengaruh terhadap berat kering simplisia umbi garut. Irisan 
membujur memiliki luas permukaan yang lebih besar dibandingkan dengan pengirisan melintang, sehingga simplisia dengan arah irisan membujur memiliki laju penguapan Iebih cepat. Simplisia umbi garut irisan membujur pada pengeringan menghasilkan simplisia yang lebih kering karena laju penguapan yang besar dan berat kering menjadi lebih kecil. Pengirisan melintang tidak mengalami laju penguapan yang tidak terlalu cepat disebabkan ukuran permukaan yang lebih kecil. Pecahnya selsel pada pengirisan melintang lebih kecil dibandingkan pengirisan membujur.

Tabel 2. Uji lanjut DMRT arah irisan terhadap berat kering simplisia umbi garut.

\begin{tabular}{cccc}
\hline \multirow{2}{*}{ Arah Irisan } & $\mathrm{n}$ & \multicolumn{2}{c}{ Mean } \\
\cline { 2 - 4 } & \multicolumn{2}{c}{1} & 2 \\
\hline A1 (Membujur) & 4 & $10,65^{\mathrm{a}}$ & \\
A2 (Melintang) & 4 & & $11,68^{\mathrm{b}}$ \\
\hline
\end{tabular}

Keterangan: angka-angka yang diikuti huruf yang sama pada kolom yang sama tidak berbeda nyata pada taraf $95 \%$ dengan menggunakan uji DMRT.

\section{Performa Simplisia}

Hasil analisis performa umbi garut yang disajikan pada tabel 4. dan pada gambar 1 dan 2 diperoleh poin total membujur $3 \mathrm{~mm}$ (6 poin), membujur $5 \mathrm{~mm}$ (4 poin), melintang $3 \mathrm{~mm}$ (5 poin), dan melintang $5 \mathrm{~mm}$ ( 9 poin), dari performa

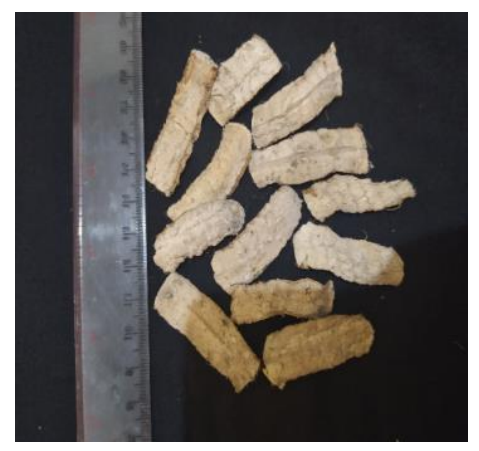

a simplisia didapatkan paling hasilnya optimal yaitu irisan melintang dengan ketebalan $5 \mathrm{~mm}$ yang menghasilkan warna coklat tua, tekstur sulit dipatahkan dan aroma yang sangat menyengat. Menurut Damayanti (2012) simplisia umbi garut kering yang baik memiliki ciri-ciri yang tidak mudah patah, aroma yang menyengat, dan memiliki warna coklat tua.

Peruhahan wama terjadi karena adanya proses oksidasi. Selama pengeringan dan penyimpanan bahan sebelum penyulingan flavonoid terjadi oksidasi yang menyebabkan terjadinya perubahan warna. Metode pengirisan arah melintang $3 \mathrm{~mm}$ (A2TI) menghasilkan warna yang pucat dibandingkan dengan yang lain setelah dikeringkan selarma 108 jam dengan oven $50^{\circ} \mathrm{C}$. Selain itu cara pengeringan yang salah dapat membuat warna simplisia kurung menarik. Cara yang kurang tepat tersebut misalnya ketika proses pengeringan bahan ditumpuk sedemikian rupa sehingga aliran udara oven yang akan masuk dalam bahan kurang lancar, sehingga bahan yang ditumpuk di bagian tengah tidak mendapatkan udara pengering yang cukup dan menyebabkan warna tidak menarik. Menurut Febriani (2013) pengeringan simplisia dengan sinar ultraviolet menyebabkan warna simplisia umbi garut menjadi pucat. Sinar lampu dan oven memiliki intensitas dan suhu relatif lebih stabil dibandingkan cahaya matahari.

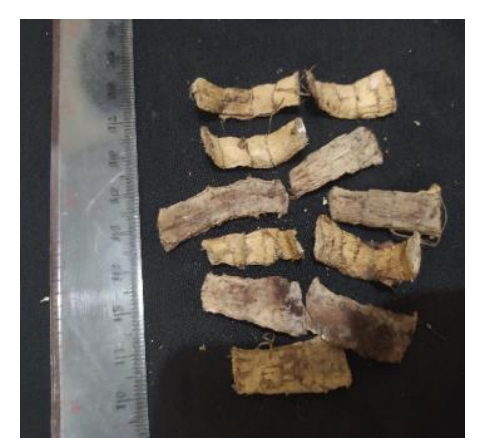

b

Gambar 1. Simplisia kering umbi garut. a). A1T1 (membujur $3 \mathrm{~mm}$ ); b). A1T2 (membujur $5 \mathrm{~mm}$ ) 


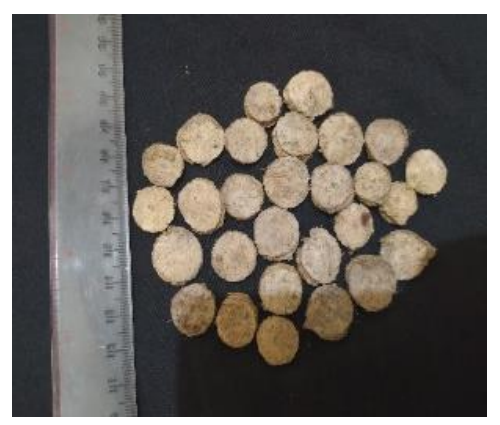

a

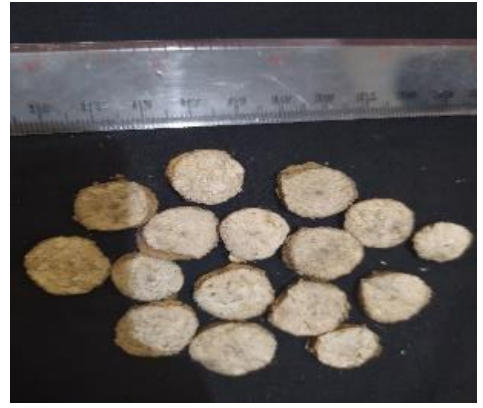

b

Gambar 2. Simplisia kering umbi garut. a). A2T1 (melintang $3 \mathrm{~mm}$ ); b). A2T2 (melintang $5 \mathrm{~mm}$ ).

Tabel 3. Data hasil performa simplisia umbi garut (Maranta arundinacea L.)

\begin{tabular}{ccccc}
\hline Parameter & A1T1 & A1T2 & A2T1 & A2T2 \\
\hline Warna & 2 & 2 & 1 & 3 \\
Kekerasan & 2 & 1 & 1 & 3 \\
Aroma & 2 & 1 & 3 & 3 \\
\hline
\end{tabular}

Keterangan:

Poin 1 : Warna kuning, tekstur mudah dipatahkan, aroma tidak menyengat

Poin 2 : Warna coklat, tekstur keras, aroma menyengat

Poin 3 : Warna coklat tua, tekstur sangat keras dan aroma sangat menyengat

Kekerasan simplisia ditentukan dari seberapa besar air yang dikeluarkan dari bahan melalui pengeringan. Air yang terkandung dalam bahan akan membuat bahan memiliki tekstur lunak. Simplisia yang diiris membujur $5 \mathrm{~mm}$ (AITI) memiliki kekerasan yang baik. Bahan yang memiliki kekerasan yang baik akan diminati konsumen karena akan memiliki ketahanan dalam penyimpanan yang cukup lama serta tidak mudah rusak. Menurut Damayati (2012) simplisia umbi garut yang baik yaitu memiliki tekstur yang keras dan tidak mudah patah, sehingga banyak diminati oleh masyarakat karena dapat disimpan dalam waktu yang lama.

Aroma yang dihasilkan umbi garut berasal dari fenol yang memiliki bau khas yang terkandung dalam bahan. Aroma fenol dapat tercium ketika dilakukan pengirisan dan pengeringan. Pengirisan yang terjadi menyebabkan rusaknya sel tanaman sehingga senyawa fenol yang terdapat pada sel tersebut dapat keluar karena senyawa fenol bersifat mudah menguap. Pemanasan dan pengeringan juga dapat menimbulkan arorma kerena menyusutnya bahan dan sel-sel menjadi pecah. Simplisia dengan pengirisan membujur $5 \mathrm{~mm}$ (A1T2) merupakan simplisia dengan arorna yang sangat menyengat. Luas permukaan yang besar akan mengakibatkan menguapnya fenol karena adanya pengeringan dan rusaknya sel-sel. Selain A1T2 memiliki kandungan air jadi lebih sedikit sehingga aromanya juga sangat menyengat.

Khoirani (2013) menyatakan bahwa aktivitas enzim hidrolase tinggi apabila kadar air simplisia juga tinggi. Enzim hidrolase tersebut dapat mendegradasi senyawa ester. Berbagai kandungan kimia terutama komponen falvonoid tertentu yang memberikan aroma khas. Hal terscbut juga ditunjukkan pada penelitian ini, dimana pada simplisia yang memiliki kadar air paling rendah yakni memiliki aroma menyengat khas tanaman umbi garut.

\section{KESIMPULAN}

Arah irisan berpengaruh terhadap berat kering dan performa simplisia umbi garut, dengan arah irisan melintang paling optimal dibandingkan yang membujur. Arah irisan tidak berpengaruh terhadap kandungan flavonoid. Tebal irisan berpengaruh terhadap rendemen flavonoid, tebal 
irisan 5mm lebih optimal dibandingkan 5mm, tetapi tebal irisan tidak berpengaruh terhadap berat kering dan performa simplisia umbi garut. Performa simplisia yang paling baik dihasilkan dari kombinasi irisan melintang dengan ketebalan $5 \mathrm{~mm}$.

\section{DAFTAR PUSTAKA}

Anwar, K., Fadlillaturrahmah, Sari, D.P., 2017, Analisis Kandungan Flavonoid Ekstrak Etanol Daun Binjai (Mangifera caesia Jack.) dan Pengaruhnya terhadap Kadar Glukosa Darah Tikus yang Diinduksi Fruktosa Lemak Tinggi, Jurnal Ilmiah Ibnu Sina 2(1), 20-30. https://doi.org/10.36387/jiis.v2i1.79

B2P2TOOT.2015. Penanganan Pasca Panen Umbi Garut. Jakarta: B2P2TOOT

Badan POM RI. (2013). Pedoman Teknologi Formulasi Sediaan Berbasis Ekstrak.Volume 2. Jakarta: Direktorat Obat Asli Indonesia, Deputi Bidang Pengawas Obat Tradisional, Kosmetik Dan Produk Komplemen. Halaman: 7-8,12-16. https://dx.doi.org/10.30821/kfl:jibt.v2i1.180 2

Djaafar TF, Sarjiman, Arlyna BP. 2010. Pengembangan budidaya tanaman garut dan teknologi pengolahannya untuk mendukung ketahanan pangan. Jurnal Litbang Deptan 9(1): 25-33.

Febrinda, A. E., Made, A., Taufik, W. \& Nancy, Y. D. (2013). Kapasitas antioksidan dan inhibitor alfa glukosidase ekstrak umbi bawang dayak (Eleutherine palmifolia 1 . merr). Teknologi dan Industri Pangan, 24(2), $1-7$.

http://doi.org/1.606066/jtip.2013.24.2.161

Harmayani E, Kumalasari ID, Marsono Y. 2011. Effect of Arrowroot (Marantha arundinaceae L.) diet on the selected bacterial population and chemical properties of caecal digesta of Sprague dawley rats. Int. Res. J. Microbiol (IRJM) 2(8): 278- 284.

Hasan, V., S. Astuti, and Susilawati. 2011. Indeks glikemik oyek dan tiwul dari umbi Garut (Marantha arundinaceae L.), suweg (Amorphallus campanullatus BI) dan singkong (Manihot atullisima). J. Tek. Industri dan Hasil Pertanian, 16(1):34-50. http://dx.doi.org/10.23960/jtihp,y,16i1.34\% $20-\% 2050$

Indrawati, Ni Luh., Razimin., .2013. Bawang Dayak: Si Umbi Ajaib Penakluk Aneka Penyakit. PT AgroMedia Pustaka. Jakarta.
Khoirani, N., .2013. Karakterisasi Simplisia dan Standarisasi Ekstrak Etanol Herba Kemangi (Ocimum americanum L) Skripsi, Jurusan Farmasi UIN Syarif Hidayatullah, Jakarta

Komala, O. 2011. Uji Daya Tahan Tepung Garut (Marantha arundinaceae Linn) Terhadap Bakteri Escherichia coli Dan Jamur Kontaminan. Jurnal AKATELKOM. Vol 10, No 3, 22-31.

Koswara, S. 2013. Teknologi Pengolahan Umbiumbian: Jurnal Pengolahan Umbi Garut. Bogor: IPB.

Laksana, Toga, .2010. Pembuatan Simplisia dan Standarisasi Simplisia, UGM: Yogyakarta.

Neldawati, Ratnawulan, \& Gusnedi, 2013, Analisis Nilai Absorbansi dalam Penentuan Kadar Flavonoid untuk Berbagai Jenis Daun Tanaman Obat, Pillar of Physics 2, 76-83.

Rini, P.E. 2009. Pasokan dan Permintaan Tanaman Obat Indonesia Serta Arah Penelitian dan Pengembangannya. Balai Penelitian Tanaman Obat dan Aromatik Indonesia (Medical and Aromatic Crops Reseach Institute): Bogor http://dx.doi.org/10.21082/p.v8n1.2009.\%25 $\mathrm{p}$

Titiek, F.D., Sarjiman, dan A.B. Pustika. 2010. Pengembangan budidaya tanaman garut dan teknologi 18 Buletin Plasma Nutfah Vol.17 No.1 Th.2011 pengolahannya untuk mendukung ketahanan pangan. J. Litbang Pertanian 29(1):25-33. http://dx.doi.org/1021082/blpn.v17n1.2011. p12-18

Trihono. 2011. Regulasi penggunaan jamu untuk terapi kedokteran modern. Prosiding Simposium Penelitian Bahan Obat Alami XV di Solo, 9-10 November 2011. http://dx.doi.org/10.25181/prosemnas.v0i0.4 32

Setyaningrum, N. E. (2013). Efektifitas penggunaan jenis asam dalam proses ekstraksi pigmen antosianin kulit manggis (garcinia mangostana L) dengan penambahan aseton $60 \%$. Skripsi, Surakarta: Universitas Sebelas Maret.

Ukoha P.O., Cemaluk E.A.C., Nnamdi O.L., and Madus E.P., 2011, Tannins and Other Phytochemical of the Samanaea saman Pods and Their Antimicrobial Activities, African Journal of Pure and Applied Chemistry, 5 (8), 237-244. https://doi.org/10.5897/AJPAC.9000161. 
Wasito, H. (2011). Obat Tradisional Kekayaan Indonesia. Yogyakarta: Graha Ilmu. Halaman: ix-1.

Winangsih dan Prihastanti, E., Parman, S. (2013). Pengaruh Metode Pengeringan Terhadap Kualitas Simplisia Lempuyang Wangi (Zingiber aromaticum L.). Buletin Anatomi dan Fisiologi.1(1), 19-25. http://doi.org/10.14710/baf.v21i1.6268. 